\title{
10th European Conference on Precision Agriculture (Part III)
}

\author{
John V. Stafford ${ }^{1} \cdot$ Paul G. Carter $^{2}$
}

This is the third and final special issue on the 10th European Conference on Precision Agriculture which took place at the Volcani Centre, Israel in July 2015. ECPA conferences come under the auspices of the International Society for Precision Agriculture. The 11th conference was held earlier this year in Edinburgh and papers are now being invited for special issues on that conference.

John V. Stafford

john.stafford@silsoe-solutions.co.uk

Paul G. Carter

cart@wsu.edu

1 Silsoe Solutions, Ampthill, Bedford, UK

2 Washington State University, Dayton, WA, USA 